\title{
Nordic Working Life Development Programs and the Tricky Problem of Scaling-up'
}

\section{Tuomo Alasoini ${ }^{2}$}

Research Professor, Finnish Institute of Occupational Health, Finland

\begin{abstract}
This paper examines Nordic working life development programs as agents of change and the possibility of working life change through such programs in general. It first constructs narratives of Norwegian and Finnish program histories based on a literature review. The narratives form the basis for a summary of the main successes, limitations, and problems of the programs. The Norwegian and Finnish experiences act as an introduction to a discussion on the shortcomings of research-aided efforts toward reforming working life more generally. The paper suggests that Transition Management, an approach widely utilized in transition and innovation studies, could also be helpful in increasing understanding about preconditions for working life change and dealing with some of these shortcomings.
\end{abstract}

\section{KEYWORDS}

Action research / development program / innovation / Transition Management / working life change

\section{Introduction}

he Nordic countries have drawn special attention due to distinctive features of their working life. Some researchers even speak of a particular 'Nordic working life model' (Mustosmäki 2017). The use of such a concept has been justified by three interrelated arguments. First, from the quality of working life (QWL) point of view, the Nordic countries can be seen as a whole. Second, working life in the Nordic countries has a sort of distinctiveness compared with working life in other European countries. Third, this distinctive quality manifests itself as a high QWL in the Nordic countries.

Different authors have given different explanations for the 'Nordic effect'. According to institutional theories, institutional frameworks mediate the global pressures for change, and they act to maintain or even widen national differences in QWL. The production regime theory argues that employment dynamics are influenced by means by which different countries coordinate economic activity, while the employment regime theory emphasizes the significance of the extent of involvement of organized labor in decisionmaking over employment policy and employment regulation. The Nordic countries are regarded as examples of 'coordinated market economies' (production regime theory) or 'inclusive employment regimes' (employment regime theory), both creating favorable conditions for a high QWL (Gallie 2007). In more 'agentic' models of explanation, the main focus is on particular forms of bi- and trilateral interaction and communication

\footnotetext{
${ }^{1}$ You can find this text and its DOI at https://tidsskrift.dk/njwls/index.

${ }^{2}$ Corresponding author: Tuomo Alasoini, tuomo.alasoini@ttl.fi.
} 
between organized labor, employers, and governments in those countries rather than on more or less 'given' or static structural features (Gustavsen 2011; Kettunen 2012; Kristensen 2011).

According to a standard view of the Fordist compromise, labor unions trade a high degree of management control over work organization for greater levels of pay and security. Such a compromise leads to Taylorist jobs that do not leave much room for discretion and autonomy at work for most employees. However, in the Nordic countries, characterized since WWII by powerful unions and a relatively high level of trust between organized labor and employers, a different kind of compromise took shape. In the Nordic version of the Fordist compromise, labor unions traded their demands for higher levels of discretion and autonomy at work for a high degree of task and working time flexibility required by employers, leading to 'saturated jobs' with high work intensity (Boxall \& Winterton 2018). The high work intensity in the Nordic countries appears in comparative studies as a high proportion of those who work at high speed and to tight deadlines, among other things (Mustosmäki 2017).

Numerous projects, programs, and campaigns for reforming working life are one manifestation of close interaction and communication between the employer and employee sides in the Nordic countries. Denmark, Finland, Norway, and Sweden have a long history of such efforts at the national, regional, and industry levels, based on cooperation between policy-makers, unions, employers, workplaces, action researchers, and consultants. Practically, all large-scale programs for reforming working life in these countries have been evaluated or otherwise thoroughly discussed in research literature, either in themselves (Arnkil 2004; 2008; Arnold et al. 2005; Gustavsen et al. 1996; 2001; Hasle \& Møller 2001; Hvid \& Møller 2001; Levin 2002) or from a broader national (Alasoini 2015; Brulin \& Svensson 2012; Hasle et al. 2017; Qvale 2002) or comparative international perspective (Alasoini 2009; Gustavsen 2007; Naschold 1994; Naschold et al. 1993). Yet, despite this large body of literature, questions concerning the potential of such programs to act as agents of change and the possibility of change in working life through such programs in general remain the subject of scant academic discussion thus far. This article takes the filling of this gap as its starting point.

This article contributes to the existing literature in three ways.

First, it presents and examines the history of Nordic working life development programs (WLDPs) in the form of milestones and short narratives, focusing on Norwegian and Finnish examples. Norway and Finland can be considered the two Nordic countries with the most ambitious programs in this area during the past 20 years.

The narratives, which are based on a literature review and my own involvement as program manager in the Finnish programs for nearly 20 years, form the basis for our second contribution - a summary of the main successes, limitations, and problems of the programs conducted thus far. The guiding idea of the analysis is that the two generic tasks of WLDPs are, first, to build as large a coalition as possible, including key institutions and organizations, in support of change, and, second, to articulate a feasible vision of new competing solutions in the form of new work-related practices for existing solutions. Coalition building is essentially a political task, while the search for new alternatives is an explorative task. Concerning the former task, the analysis targets dynamics within the field of industrial relations and between different policy domains. Concerning the latter task, the focus is on the role of action (social) researchers in the programs.

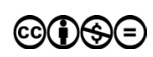


The added value of the review compared to the numerous previous analyses on the subject (see above) is twofold. First, the review takes the 'helicopter perspective' on the long-term development of WLDPs in both countries and summarizes this in a form of a few milestones and a narrative that tries to crystallize the most essential features of each decade. The 'helicopter perspective' is based on a meta-analysis of published evaluation studies on different Norwegian and Finnish programs, supplemented with reflective articles of action researchers in both countries, my own previous analyses on the subject (e.g., Alasoini 2006, 2009, 2011, 2014, 2015), and my long experience as an 'insider' in the practical implementation of Finnish programs. Second, the review is based on a framework that seeks to uncover the successes and, in particular, shortcomings of the programs, paving the way for our third contribution.

New insights into what should and could be done to deal with the problem of the 'limited impact' of WLDPs is our third contribution. Here, the focus is not so much on Norwegian and Finnish programs but on research-aided efforts to reform Nordic working life more generally. Based on the summary of the successes and shortcomings of Norwegian and Finnish programs, I try to increase understanding about how to build more effective programs by drawing on sociological theorizing and showing how this can contribute to practice. I especially try to elaborate viewpoints presented by Gustavsen (2017) in NJWLS, by examining research-aided efforts to reform working life within a framework influenced by the Transition Management approach. The elaboration leads to the claim that programs aiming to reform working life would need to be guided by a more explicit conceptualization of the preconditions for working life change.

This article continues with a description of the key Norwegian and Finnish program-based efforts to reform working life. This is followed by a summary of the main achievements and shortcomings of the programs. Thereafter, I try to show how these shortcomings can be better understood with the help of sociological theorizing based on the Transition Management approach. Finally, conclusions are discussed.

\section{Program history of Norway and Finland}

This chapter contains a list of the milestones of program history in Norway and Finland, and it presents two country narratives based on such milestones. Norwegian programs have been a topic of international interest since the 1960s, while Finnish programs started to gain international attention only in recent years. There are already numerous presentations on both countries' programs (as mentioned above), a fact that forms a sound basis for depicting an overall picture of the programs' role in promoting working life change in both cases.

\section{Milestones in Norway}

Norway is the pioneer in Europe; its history of experiments in job redesign and workplace democracy dates back to the early 1960s (Table 1). In 1962, the central labor union organization LO and the employers' central organization NHO launched a cooperation project for the promotion of industrial democracy, including research and 
development activities in a number of industrial enterprises. Social psychologist Einar Thorsrud, who was appointed a project manager, had had his first contacts with the Tavistock Institute of Human Relations in London as early as 1945. This close relationship contributed to working life development in Norway becoming heavily influenced by action research and sociotechnical work design from the beginning. Thorsrud was also appointed the first director of the new Work Research Institute (originally named the Institute of Work Psychology), which was established in 1964 as a merger of institutes.

The readiness of labor market organizations to increase value creation in companies through broad cooperation culminated in an agreement on enterprise development between LO and NHO in 1982. The agreement did not express views on organizational design principles but focused instead on the processes needed to create a 'good organization'. The main instrument in pursuing this goal is an ongoing Joint Action Program (HF-B). According to Gustavsen (2014), by 2010, approximately 2000 companies had used funding received from HF-B to arrange labor-management dialogue conferences or to launch research and development projects.

In 1988, the government launched a five-year program entitled the Centre for a Better Working Life (SBA). A noteworthy feature in SBA was that democratic participation was for the first time in Norway recognized as an important industrial policy issue for the promotion of productivity, rather than being seen as an issue that has significance solely from an industrial relations perspective (Qvale 2002). The program, which reached 300 enterprises, drew attention among an international audience and was internationally benchmarked (Naschold 1994).

The cooperation structures that have emerged and have been developed between LO and NHO have also formed the framework for ambitious R\&D programs such as Enterprise Development 2000 (ED 2000) and Value Creation 2010 (VC 2010). ED 2000 was a pathbreaker in that it was not built on projects in individual companies but on larger (mainly regional) development modules comprising several enterprises and research organizations (Gustavsen et al. 2001; Levin 2002). In VC 2010, the sphere of intervention was extended from intrafirm organizational processes and interfirm networking to intra-regional processes. However, the Research Council of Norway terminated VC 2010 after a mid-term evaluation (Arnold et al. 2005) and merged it in 2007 as part of a new larger program entitled the Funding Program for Regional R\&D and Innovation (VRI). ED 2000 involved close to 100 enterprises, while more than 350 enterprises were involved in the VC 2010 networks by the time the program ended (Hildrum et al. 2009).

\section{Table I Milestones in Norway}

- Industrial Democracy Program (1962)

- Establishment of the Work Research Institute WRI (1964)

- Agreement on enterprise development between LO and NHO (1982): Joint Action Program HF-B still ongoing

- Centre for a Better Working Life program (SBA, 1988-93)

- Enterprise Development 2000 program (ED, 1994-200I)

- Value Creation 2010 program (VC, 200 I-07)

- Funding Program for Regional R\&D and Innovation (VRI, 2007-17) 


\section{Milestones in Finland}

Finland does not have the same rich history in workplace-level action research projects and sociotechnical experiments that Norway has become famous for since the 1960s (Table 2). This can be partly explained by a higher level of industrial conflict in Finland and, especially since the 1970s, Finnish employers' general suspicion of 'too radical' academic researchers. Finnish labor unions, too, had an aspiration to one-sidedly push through renewals in working life through legislative reforms. The promotion of industrial democracy did not happen in Finland through cooperation projects between employers and unions but through a political struggle that, in 1978, resulted in the enactment of the Act on Cooperation within Undertakings. Principles for good conduct in the event of workplace changes were laid down by rationalization agreements between the employers' central organization STK and the central labor union organization SAK and corresponding development agreements between STK and white-collar employees' central organizations that were signed in the 1980s. However, these developments did not lead to the emergence of similar cooperation structures as in Norway.

The establishment of the Finnish Work Environment Fund in 1979 marked an improvement in funding opportunities for applied research into working life and paved the way for increased cooperation between labor market organizations in this area. Action research, which had never gained a significant foothold in Finnish working life research, was strengthened in the 1980s with the establishment of new units in universities and research institutes (Ramstad \& Alasoini 2006). In the late 1980s and early 1990s, approximately 10 major action research inspired projects were launched. Characteristic of this 'first generation' of action research on working life in Finland was its multidisciplinary nature and that it involved work organizations from many different sectors (Kauppinen \& Lahtonen 1994).

The National Productivity Program that was launched in 1993 on the initiative of labor market organizations may be regarded as the first actual national-level R\&D program for reforming working life in Finland. During its 10 years of operation, the program funded 40 applied research projects for the improvement of productivity, quality, and employee well-being. In 1996, the Productivity Program was complemented by the Workplace Development Program TYKE, which was launched by the government. The TYKE program focused on workplace-level development projects in individual companies and public organizations and their networks. In 2004, these two programs were merged as the new Workplace Development Program TYKES. During 1996-2010, more than 1800 projects were funded through the TYKE and TYKES programs, of which more than 1500 comprised development projects started by workplace initiatives (Alasoini 2015).

In 2011, the government decided to draw up a National Working Life Development Strategy for Finland. The strategy was completed in 2012. Its vision is that Finland will have the best working life in Europe in 2020. The Ministry of Employment and the Economy established the Working Life 2020 (WL 2020) umbrella project for implementing the strategy as a network of 80 public, private and nongovernmental institutions. As part of the strategy, Tekes (Finnish Funding Agency for Innovation) launched a program entitled 'Liideri - Business, Productivity and Joy at Work', focusing on business development through improvements in management, ways of working, and employees' participation in innovation (Alasoini 2015). Labor market organizations have launched 12 joint development programs in different sectors and industries under the WL 2020 framework. 
Table 2 Milestones in Finland

- Establishment of the Finnish Work Environment Fund (1979)

- Rationalization and development agreements between central labor market organizations (1980s)

- Rise of action research on working life in universities and research institutes (late 1980s)

- National Productivity Program (1993-2003)

- Workplace Development Programs TYKE and TYKES (1996-2010)

- Working Life 2020 umbrella project (2012-2019), including the Liideri - Business, Productivity and Joy at Work program (20|2-20|8)

- Industry-wise joint workplace development programs between labor market organizations (since the early 2010s)

\section{Norwegian narrative}

Despite their aspiration to promote industrial democracy and self-managing forms of work organization through joint action, labor market organizations and action researchers in Norway did not succeed particularly well in mainstreaming experiments conducted in pioneering companies in the enterprise field more widely (Table 3). The 'flying start' collided with many obstacles in the 1960s and 1970s (Qvale 2002). The favorable consensual climate of industrial relations was insufficient to help enterprises on a broader front to overcome their cautious attitude toward the benefits of research and, in particular, action research. Moreover, the assumptions of how to proceed from a small number of (successful) experiments carried out in particular workplace contexts to a wider diffusion of the results of these experiments was based on overoptimistic premises.

The SBA program was preceded by a thorough preparation on the part of the government, marking an attempt to bring the idea of democratic participation to the industrial policy agenda. It was still an unresolved question in the 1980s how the country's high-trust industrial relations would be made to better serve the development of productivity and of the competitiveness of the country. The overall conclusion was that SBA succeeded only in part in achieving this goal (Naschold 1994; Qvale 2002). Among the many reasons for its 'limited success', one could mention, in particular, the difficulty of dialogue between actors of different policy domains and the discrepancy between the ambitious goals of the program and program resources in terms of funding, available research expertise, and time-scale.

The Enterprise Development 2000 program emerged in the 1990s as an alliance between NHO, LO, and the Research Council. In the beginning, ED 2000 encountered many difficulties associated with its high ambitions and the diversity between the interests of different stakeholder groups, such as employers vs. unions, representatives of applied social research vs. technological research, representatives of action research vs. academic 'normal science', and between different modules. However, ED 2000 managed to overcome many of these problems and it became a learning process for those involved, creating new, workable network-based forms of development and raising the legitimacy of action research in the eyes of companies, labor market organizations, and the academic community (Gustavsen et al. 2001; Levin 2002; Qvale 2002).

The Value Creation 2010 program was a follow-up for ED 2000 with somewhat greater resources and even higher ambitions. Funding in VC 2010 focused exclusively on the work input of researchers in large regional projects that covered the whole country. 
The aim was that the researchers would operate on and make a simultaneous contribution to the enterprise level, the enterprise network level, and the regional level. However, the political backing of VC 2010 was weaker and the three-party alliance not as strong as in ED 2000. Based on a mid-term evaluation, which criticized the program for, among others, a number of lock-ins and a too ambitious goal setting in relation to available resources and research expertise (Arnold et al. 2005), the Research Council decided to terminate the program in its current form.

The termination of VC 2010 and the integration of some its activities in the new VRI program marked a return to a more traditional view of the division between 'development' and 'research'. This shift also narrowed the role reserved for action researchers in the program. Moreover, the link to working life reform in VRI was less direct, and the scope of issues that could be funded was broader than in preceding programs, leaving less space for action research on working life (Hildrum et al. 2009). Nevertheless, close cooperation between labor market organizations in order to increase value creation within companies has continued in the 2010s under the framework of HF-B. Labor market organizations, in cooperation with the Ministry of Trade and Industry, have tried to give an extra boost to participatory innovation practices in companies by promoting the idea of 'employee-driven innovation' and gathering 'good practices' in support of such innovation (Hansen et al. 2017).

\section{Finnish narrative}

The Finnish narrative differs from the Norwegian one in its much shorter period of program-based development (Table 4). Finland can be characterized as a latecomer to

Table 3 Norwegian narrative

\begin{tabular}{ll}
\hline 1960s and 1970s & Start of experiments to promote industrial democracy enabled by consensual \\
& industrial relations, but the 'flying start' is poorly utilized due to a low level of \\
& interest among companies to utilize research in support of their development and \\
& deterministic views on the diffusion of innovations and learning from 'good practice'. \\
\hline 1980s & Democratic participation also recognized as an important industrial policy issue \\
& for the improvement of productivity (SBA), but this shift of mind-set is difficult to \\
& realize due to institutional rigidities among labor market organizations and industrial \\
& development agencies and the lack of skilled action researchers. \\
\hline 1990s & \begin{tabular}{l} 
Increased appreciation of action researchers in the eyes of companies, labor market \\
organizations, and the academic community through involvement in transdisci- \\
plinary knowledge production for solving practical problems and arranging 'discur- \\
sive platforms' within inter-company networks of ED 2000. \\
\hline Start of the ambitious VC 20IO program and its revision after a mid-term evalu- \\
ation indicating lock-ins concerning the type of industry, innovation, research, and \\
region, and a limited suitability of action researchers to address processes of the \\
intra-regional level.
\end{tabular} \\
\hline Continued close cooperation between LO and NHO under the HF-B framework \\
and a more limited and traditional role for researchers in the VRI program.
\end{tabular}


the Nordic working life model. The union density in Finland reached the level of the other Nordic countries only in the early 1970s, and industrial relations were strained until the late 1980 s, owing to power struggles within the trade union movement and a high propensity for strikes (Lilja 1992). Finland also lacked academic figureheads such as Einar Thorsrud and Bjørn Gustavsen, who would have had close and confidential relationships on both the employer and employee sides and thus would have been able to bring action research to their joint agenda. The basic conditions for WLDPs were created in Finland only in the 1980s, as mentioned above.

The 1990s marked a breakthrough in action research and programs for reforming working life in Finland. Unlike Norway, the underlying discourse to which the first Finnish programs were related was not so much the promotion of industrial democracy and QWL as such but productivity- and competitiveness-related problems and an attempt to integrate the development of working life as part of mainstream innovation policy thinking. In this regard, the programs were only partly successful. On the one hand, both the TYKE program and the Productivity Program were continued in 1999 for an extra four years in good agreement between the government and labor market organizations, and the TYKE program received an extra funding through the Science and Technology Policy Council. On the other hand, the gap between the starting premises of TYKE and mainstream innovation policy remained wide, hampering the full inclusion of working life development in the innovation policy agenda (Arnkil 2004; Piirainen \& Koski 2004).

The position of program-based development of working life was further strengthened in the 2000s with the launch of the TYKES program and a number of other smallerscale programs by various governmental and semi-governmental organizations. This opened new opportunities for action researchers to participate in workplace-level development projects. At the same time, working life researchers, social researchers in the foreground, strengthened their mutual networks by creating an association and starting to publish a peer-reviewed journal and arranging annual research conferences. Further steps to increase the integration between the promotion of workplace innovation and mainstream innovation policy were taken in 2008, when the government adopted a new national innovation strategy under the heading 'broad-based innovation policy' and shifted the coordination of TYKES from the Ministry of Labor to Tekes, the largest public innovation funding agency in Finland (Alasoini 2011).

In the 2010s, working life development has maintained its position in the political agenda with the continuation of Working Life 2020 until the end of the decade and the launch of several industry- and sector-wide joint programs between labor market organizations. However, WL 2020 acts as an umbrella for coordinating the activities of a large number of actors with only a small budget of its own. The input of academic research in WL 2020 is minor. Similarly, labor market organizations' joint programs primarily deal with issues that have relevance from their own perspective, leaving little room for action research. The Liideri program funded both development projects and research projects, but - like the Norwegian VRI program - it did so by resorting to quite a traditional distinction between 'development' and 'research', in line with the tradition and regulations of Tekes. The closer integration of the promotion of workplace innovation in the overall target of Tekes to promote business growth and development also reduced the significance given to QWL and employee participation in the Liideri program in comparison with the previous TYKE and TYKES programs.

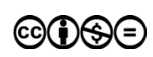


Table 4 Finnish narrative

\begin{tabular}{ll}
\hline 1960s and 1970s & Labor market organizations not ready to promote industrial democracy through \\
& collaborative joint action or with the help of social scientists due to a high level \\
& of mutual distrust and industrial conflict and employers' general suspicion toward \\
'too radical' academic researchers.
\end{tabular}

\section{Successes, limitations, and problems of the programs}

This chapter summarizes the major achievements and shortcomings of the programs based on the two narratives. The first section provides an overview of the role of different actors in Norwegian and Finnish programs from a comparative perspective. Thereafter, I examine the programs' successes, limitations, and problems.

\section{Roles of different actors}

The ability to produce new, competing solutions and help implement them as 'workplace innovations' and the ability to build broad coalitions in support of change can be regarded as two generic tasks of programs aiming to reform working life. The former (explorative) task and the latter (political) task require different skills and resources. It is therefore easy to understand that the involvement of different types of actors and their cooperation in programs is necessary. According to the 'expanded triple helix model' (Ramstad 2009), three key groups of actors with different contributions in WLDPs can be distinguished: policy-makers, R\&D units, and workplaces. Naschold (1994), using a grouping based on the need for different 'systems' in programs, makes a distinction between the industrial policy system, the industrial relations system, and the research and development system.

Following the logic of these two frameworks, the function of the industrial/innovation policy system is to provide general frameworks for directing program activities. This 
is particularly important with respect to ensuring the relevance of program goals from the point of view of the operational development needs of involved workplaces. The function of the industrial relations system is to safeguard and strengthen the social legitimacy of program activities and, in particular, to help to maintain the balance between the interests of employers and employees through a link between improvements in productivity and QWL. The function of the research and development system is to ensure the insightfulness of program activities with a view to generating novel, workable, and research-based solutions for reforming working life.

The program histories of Norway and Finland not only reveal many similarities but also many differences in the dynamics of the three systems. The two main differences are, first, the more direct link between the industrial relations system and the research and development system in Norway and, second, the more prominent role of governments and the industrial/innovation policy system in Finland.

In Norway, it is possible to detect a quite direct impact of social science thinking on program designs through research institutes like the WRI, the Norwegian University of Science and Technology (NTNU), and the Foundation for Scientific and Industrial Research (SINTEF). Over the years, action researchers have acted as an important source of influence for programs and renewals in working life, in cooperation with labor market organizations and the government. However, problems have emerged when the focus has moved from the industrial relations framework into the innovation, industrial, and regional policy arenas in which labor market organizations are not dominant actors and in which action researchers have not had so much experience of acting.

In Finland, no such direct link between research and program designs can be found. The program rationale originated in the early 1990s through mutual discussions between the Ministry of Labor and labor market organizations from problems with the productivity and competitiveness of Finnish companies and the idea of a 'system failure' seen through an innovation system framework. Workplace innovation was considered a neglected area in the national innovation system, and a 'soft' governmental intervention in the form of programs was considered a legitimate approach to meet this failure. Unlike in Norway, where social science thinking and action research have played a considerable role at the strategic level in programs, in Finland, this role has been important only at the operational level as a means of realizing program strategies.

Another difference between Norway and Finland concerns the role of government. In Norway, efforts to develop working life through programs, campaigns, or other similar activities have mostly originated from the initiatives of labor market organizations. The backbone of this development has been the confidential relationship between LO and $\mathrm{NHO}$, which has enabled the joint action of these two parties already for many decades. The Finnish approach has been more state-centric. Finland's more strained relationship between labor market organizations has maintained a tradition, in which government engagement has often been necessary and is considered in many cases a desired alternative to initiatives of labor market organizations even by these organizations themselves.

\section{Main successes of the programs}

It is not easy to make a detailed list of successes of programs conducted in two different countries over a long time-period. The breakdown that follows is based on a similar 
meta-analysis as the narratives, trying to summarize observations made in the research literature. The analysis reveals four main areas of success:

(1) Improvements in productivity and QWL in workplaces participating in the programs. Improvements have mostly taken place through the adoption of new management, organizational, and other work-related practices. Ideally, the adoption has been based on 'local re-invention' of these practices, supported by broad employee participation, and close cooperation between management and employees, on the one hand, and between action researchers/consultants and workplace practitioners, on the other hand, during the change process (Gustavsen et al. 1996, 2001; Ramstad 2014).

(2) Creation of collaborative relationships between workplaces and academic researchers. In both countries, action researchers have played an important role in workplace-level change processes. Unlike in many other countries, blurring the division between 'research' and 'development' in the programs, promoting the involvement of action researchers in workplace-level change processes, and supporting the further education of researchers as part of those processes have been explicit goals in both countries (Alasoini 2009).

(3) Creation of platforms for bold experimentation, both within workplaces and as larger networks. Examples of such platforms that have been tried out in Norwegian and Finnish programs include dialogue conferences, change laboratories, development modules, network projects, learning networks, and regional main projects (Alasoini 2014; Ekman et al. 2011; Gustavsen 1992; Levin 2002; Ramstad 2009; Virkkunen \& Newnham 2013).

(4) Promotion of democratic discourse within workplaces (and in society at large). Ennals and Gustavsen (1999, p. 160) argue that the Nordic countries are leading the rest of Europe in the spread of dialogical development approaches. In their argument, they refer to openness and equality of dialogue between all relevant parties involved in development and not only to interaction and cooperation that is limited to workplace management and personnel. Their claim finds empirical support from a comparative study that shows that process orientation and employees' opportunities to influence the content of project activities in both Norwegian and Finnish programs can be considered particularly strong compared with the programs of non-Nordic countries (Alasoini 2009). However, it is a more open question to what extent this has contributed to the spread of democratic attitudes and practices in wider society (on 'positive upward democratic spill-overs', see Budd et al. 2018).

\section{Main problems and limitations of the programs}

Here, using a similar approach as in the previous section, I only briefly summarize the main shortcomings, taking a more profound view on them and their causes in the next chapter. The analysis reveals four main problem areas:

(1) The problem of diffusion. This refers to the difficulty of making knowledge derived from individual (mainly workplace-level) projects in the programs better serve a larger group of workplaces and other stakeholders. This problem can be regarded 
as a major shortcoming because the legitimacy of publicly supported interventions, such as programs, cannot be based primarily on the success of individual (demonstration) projects but rather must be justified by a variety of positive externalities, such as knowledge spill-overs and network effects, produced by the intervention. Despite many innovative experiments in Norwegian and Finnish programs (Alasoini 2014; Arnkil 2004; 2008; Arnold et al. 2005; Gustavsen 2014; Levin 2002), no panacea to this problem has been found thus far.

(2) Scarcity of substantial breakthrough innovations. Examples of workplace innovations that would have seriously undermined prevailing dominant logics in working life are rare in the programs. Using concepts derived from the Transition Management literature (for more details, see the next chapter), the programs have not succeeded particularly well in scaling-up innovations that can challenge dominant ways of thinking, doing or organizing at the level of societal systems (Van den Bosch \& Rotmans 2008). The WLDPs in both Norway and Finland have been more successful in accelerating trends already ongoing.

(3) Vague conceptualization of working life change. Programs have aimed at reforming working life, but no explicit conceptualization of the preconditions for such a change has steered their implementation or emerged from their experiences. A similar criticism can be said of program evaluations, which have been more linked with the special features of the programs in question and to the special interests of the parties who requested the evaluation study than driven by an aspiration to develop such theorizing. Consequently, the knowledge created by individual evaluation studies has not accumulated.

(4) Difficulty gaining policy legitimacy outside the industrial relations system. Despite many differences in their origins, the first programs in Norway and Finland started at the initiative of actors of the industrial relations system. Gaining approval for the ideas that workplace innovations, QWL, a good work environment, broad employee participation, and labor-management cooperation are of crucial importance for companies and the industry also from the productivity point of view has not been straightforward in either country. Both countries have made progress on this issue in recent years. However, this has taken place at the expense of losing some of the most innovative elements in those efforts, as the experiences of recent programs (VRI and Liideri) show.

\section{How to deal with the problem of 'limited impact'?}

This chapter tries to further our understanding of the reasons for program shortcomings by linking the above observations with sociological theorizing based on Transition Management. Transition Management is a crossover of many theoretical underpinnings, above all evolutionary economics and constructivism as well science and technology studies, structuration theory, and neo-institutional theory (Geels 2010, 2011). First, I review viewpoints by previous authors on ways of improving the social effectiveness of programs. Next, I present Transition Management as a new approach to the discussion on the social effectiveness of WLDPs, and finally, this approach is applied to capture their dynamics. 


\section{Glance at previous research literature}

Many of the analyses and comparative presentations of WLDPs implemented in the Nordic countries over the past few years are rich in content but are mainly descriptive in nature. Only in a few cases have researchers taken the target of developing frameworks for distinguishing generic program characteristics as conducive to having a deep impact on working life (e.g., Brulin \& Svensson 2012; Gustavsen 2017; Naschold 1994; Ramstad 2009). The problem with these efforts is twofold. First, they are based on different conceptual premises, and they are not connected to each other. The accumulation of research knowledge would require the use of jointly agreed-upon concepts, models, and heuristics. Second, these efforts are not (at least explicitly) connected to any recognizable theory of change, which would help improve understanding of the possibility of working life change through such programs in general.

In particular, Gustavsen, in many of his writings, has addressed the issue of the 'limited impact' of programs under headings such as the 'problem of diffusion' (Gustavsen 2014), the 'problem of the single case' (Gustavsen 2003), and the 'problem of how to move back and forth between general theory and local action' (Gustavsen 2017). Here, Gustavsen's last-mentioned article in NJWLS forms fertile ground for further discussion. In the article, he states that WLDPs implemented in the Nordic countries have succeeded in proving positive links between participatory and democratic forms of work organization and productivity and that positive links between such forms of work organization and innovation are 'as yet more tentative' (Gustavsen 2017, p. 117). However, the programs have been less successful in making 'more substantial breakthroughs in terms of sociotechnical improvements and innovations' (Gustavsen 2017, p. 117). Gustavsen suggests two ways of addressing this shortcoming. The first set of corrective means concerns how programs are designed. This includes expanding program budgets and timespans and strengthening the links of WLDPs with other initiatives such as technology programs. The second set concerns the role of research itself. Here, his leading thought is that research should be able to help better link several local and parallel processes of workplace-level change and bring about something like a social movement through comparing these parallel local experiences and learning from them (Gustavsen 2017, pp. 117-118).

At the general level, it is easy to agree with Gustavsen's views. However, his analysis remains vague in two respects. The first concerns his way of conceptualizing working life change. The second concerns his view on the role of research in such change.

First, Transition Management makes an essential distinction between broadening and scaling-up innovation (Van den Bosch \& Rotmans 2008). The 'problem of diffusion' (see above) is the problem of broadening innovation. A social movement, as suggested by Gustavsen, can be a powerful vehicle in promoting the diffusion of new innovative practices into a larger group of workplaces and helping those practices take on new, more sophisticated forms. Scaling-up innovation means challenging dominant ways of thinking, doing, or organizing at the level of societal systems. Gustavsen's aim is to find ways of scaling-up innovation (finding ways in which a program's role in producing substantial breakthrough innovations could be improved), but his vision, in practice, mainly deals with the 'diffusion problem', that is, broadening. He writes that programs that are capable of bringing about social movements can act as 'meso-platforms' from 
which 'it may be possible to continue "upwards" toward the continuously more general' (Gustavsen 2017, p. 118). The vagueness of his argument here stems from the fact that he does not have an underlying theory of how to conceptualize the preconditions for working life change against which he can mirror his argument.

Second, Gustavsen gives a key role to research as an engine of social movements to bring about change. This requires that it is possible for research to take a neutral position in relation to different interest groups. Research may, of course, manage to take this kind of role, but this is exceptional and is an ideal case rather than reality in most cases. Moreover, social life is driven not only by economic rationality but also by powerful tendencies to strengthen the actors' political and institutional legitimacy (DiMaggio \& Powell 1983). In WLDPs, various actors may have an inherently contradictory relationship toward the development of innovations that could challenge dominant practices in working life because, in many cases, those actors also play a supportive role in societal systems that keep up such practices. This problem, called the 'paradox of embedded agency' (Battilana et al. 2009), is something that programs must deal with.

\section{Transition Management approach}

Transition Management and its key middle-range theory, the multilevel perspective (MLP), were developed in the 1990s and 2000s in order to analyze the change dynamics of complex systems and to influence transitions toward sustainable directions based on a better understanding of such dynamics. So far, the MLP has been used mostly in transition and innovation studies to analyze changes in infrastructure systems, such as energy, transport, health care, or food production, but conceptually, it could be applied to almost any type of complex social system of different levels (Geels 2011; Weber \& Rohracher 2012). Although Transition Management originated outside the sphere of working life studies, its constructivist ontology (Geels 2010) and its normative aspiration to explore and promote system-level changes toward environmentally sustainable solutions are well matched with the tradition of participatory action research for promoting socially sustainable forms of work organization.

According to the MLP, the operation of societal systems that fulfil certain societal needs is guided by a dominant logic that is embodied in established daily practices, routines and behaviors, perceptions, mental models and values, and institutional, physical, and economic structures. Established constellations of such elements are called sociotechnical regimes. Under normal conditions, regimes provide strong structuration characterized by stabilized rules and established social networks. However, they are never fully impervious to change but can be described under normal conditions as 'dynamically stable' (Geels \& Schot 2007, p. 406).

Fully fledged transitions of regimes are long, complex, and dynamic processes. According to the MLP, regimes change through the interaction between pressure arising from new niche-innovations that deviate from mainstream practices adopted by regimes, external tension that landscape changes bring to bear on existing regimes and stress within regimes owing to internal misalignments among their elements. In contrast to sociotechnical regimes, niche-innovations experience weak structuration characterized by poorly articulated structures and small and precarious social networks. Competition 
between niche-innovations and institutionalized mainstream practices that are integral elements of incumbent regimes is based not only on the features of the niche-innovations and mainstream practices but also on the features of the institutional environments in which they operate. For this reason, it is difficult even for the most promising nicheinnovations to develop into mainstream practices without simultaneous and favorable landscape changes and/or a simultaneous opening of incumbent regimes to changes. The landscape forms an exogenous environment in which economic, technological, political, social, cultural, demographic, etc., changes take place beyond the direct influence of regime actors or niche-innovation actors (Geels 2004; Geels \& Schot 2007; Smith et al. 2005).

The Transition Management literature provides conceptualizations and models for understanding the dynamics on and between the three different levels (niche-innovations, regimes, and landscape) as well as tools for managing these dynamics. Research conducted under Transition Management has generated new knowledge of, for example, antecedents of niche-innovation development, alternative pathways of sociotechnical transitions and policy mixes, and governance approaches for directing transitions toward sustainable solutions (Geels 2004; Geels et al. 2016; Geels \& Schot 2007; Kivimaa \& Kern 2016; Schot \& Geels 2008; Smith et al. 2005; 2010; Van den Bosch \& Rotmans 2008). Many of these conceptualizations, models, and tools have potential wider applicability. Next, I discuss how the outcomes of this research could benefit the design and implementation of efforts to reform working life.

\section{Transition Management and shortcomings of the programs}

Transition Management did not originally develop for solving problems defined by working life studies. The ultimate goal of Transition Management is a sociotechnical transition, which means a change from one regime to another with an increased ability to meet a certain societal challenge. The application of Transition Management to working life development requires that the system to which the development intervention aims to contribute be clearly defined. I suggest here that it is also possible to conceptualize working life as a complex societal entity that comprises a number of sociotechnical regimes. These regimes concern, for example, how work is led, managed, and organized ('management and work organization regime'); how decisions about the terms and conditions of employment are made ('industrial relations regime'); how employees' skills and competences at work are developed ('skills development regime'); and how employees' safety and health are protected and their well-being at work is promoted ('occupational safety and health regime'). Such regimes could be further divided into smaller thematic entities or analyzed at different levels, such as at national, industry, region, or ecosystem levels. Just as in the case of the regime, in working life research and development, it is possible to find functional equivalents to the concepts of nicheinnovation and landscape.

As mentioned above, the Transition Management literature provides conceptualizations, models, and tools for capturing the dynamics of regimes, niche-innovations, and landscape, many of which also have applicability in working life research and development. In the following, I take a closer look at how Transition Management can contribute to better understanding of some of the shortcomings of WLDPs (see above). 


\section{Framework for desired change}

The MLP provides a general framework in which efforts for reforming working life can be positioned. Positioning requires a clear-cut understanding of the regime to be affected, the landscape and innovations under development as well as a jointly accepted view among program stakeholders regarding the purpose of the intervention as seen through this framework. Landscape changes have often been important drivers for programs, and they have increased the leeway for experimenting with new solutions. Programs have typically acted as 'niches' in which innovations have been nurtured, developed, and (partly) sheltered from the pressures of incumbent regimes. At the same time, only rarely have programs included means that have directly or deliberately aimed at destabilizing incumbent regimes. Participatory and skills-enhancing forms of work organization have been among key objectives in most Nordic WLDPs in recent years. However, in practice, it is difficult to promote the diffusion of such forms of work organization without deliberately also undermining the foundations of the existing (e.g., Taylorist) management and work organization regime and related industrial relations, skills development, occupational safety and health, etc., regimes at the same time. One could tentatively argue that regime destabilization has remained a poorly conceptualized 'blind spot' in WLDPs owing in part to the lack of a plausible theory of the preconditions for working life change steering their implementation.

\section{Broadening innovation}

In Transition Management, broadening innovation is a necessary precondition for scaling-up innovation (Van den Bosch \& Rotmans 2008). Through broadening, an innovation becomes more diversified and better articulated, promotes learning associated with it, and strengthens networks supporting its breakthrough. Schot and Geels (2008) have distinguished three processes for the successful development of niche-innovations. The first is the clear articulation of expectations and visions related to the innovation. These expectations and visions must be specific enough to provide guidance and to become broadly shared, but not too rigid to dampen creativity and flexibility. The second process is the building of social networks. These networks should be broad and should include multiple stakeholders, but not so broad that the focus becomes lost. Third, learning processes that lead to the accumulation of facts and data need to take place, including both first-order and second-order learning. This classification is well in accordance with most discussions held in working life research and development on how to meet the diffusion problem (Alasoini 2011; Brulin \& Svensson 2012; Gustavsen 2017; Qvale 2002; Totterdill et al. 2016), but it has never been made conceptually as explicit in these discussions. Neither have programs been designed in accordance with this logic.

\section{Scaling-up innovation}

Usually, in working life studies, no conceptual distinction between broadening and scaling-up innovation is made. This lack of conceptual precision has made discussion on the social effectiveness of WLDPs difficult. In Transition Management, this distinction is of 
crucial importance (Van den Bosch \& Rotmans 2008). Scaling-up, unlike broadening, means that an innovation develops in strength and importance so that it can challenge incumbent regimes and the mainstream practices attached to them. Scaling-up can take place in two main ways. The first is that niche-innovations grow and cluster from the level of individual experiments to a competing niche-regime, which may gradually take over and lead to dissolution of the old regime. Alternatively, it is possible that the incumbent regime will take some elements of the niche-innovations and embed them within the regime as new practices, structures or cultural forms.

The change dynamics in these two cases are quite different from the viewpoint of development interventions. In the first case, there is competition between the incumbent regime and the niche-regime. The focus of the intervention is on the development of niche-innovations, probably supplemented with measures aiming at destabilizing the incumbent regime. In the second case, the coevolution of and interaction between the incumbent regime and niche-innovations is necessary. It is easy to understand that in WLDPs, the second option is, in most cases, more realistic; key program stakeholders usually play an important underpinning role also in regimes that niche-innovations are supposed to challenge.

By applying this framework to WLDPs, it is possible to derive four ways in which working life change through programs can be promoted. First, programs must have the means available of experimenting with workplace innovations in various contexts, supporting the articulation, network-building, and learning processes around these innovations. Second, the development of workplace innovations must be aligned with developments in the landscape. The two other ways concern the incumbent regime and its relationship with the workplace (niche-)innovations. Third, stress within the regime should be increased and thus pave the way for new elements to take over. Regime destabilization means undermining regime actors' confidence in the functionality of practices, structures, or cultural forms attached to the regime. Major disruptions in the landscape (e.g., technological advances) often in themselves make the regime increasingly susceptible to change (Geels \& Schot 2007). Fourth, coevolution of the incumbent regime and innovations developed within programs should be encouraged. As mentioned above, it is possible that in many cases, key actors in the programs play a dual role as representatives of institutions that at the same time are committed to underpinning incumbent regimes. To overcome this 'double bind', programs should also have the means available of promoting the 'institutional entrepreneurship' (Battilana et al. 2009) of such actors in its various forms.

\section{Discussion and conclusions}

This article has three objectives. First, it constructed narratives of Norwegian and Finnish program histories based on a literature review. The guiding idea was to form an exemplary picture of how Nordic programs have tried to fulfil their political and explorative tasks. Second, with the help of the 'helicopter perspective' provided by the narratives, four main success areas and four main problem areas were revealed. Finally, I used Transition Management as a new approach for examining and dealing with some of the shortcomings of research-aided efforts to reform working life more generally. My purpose was to further develop the viewpoints raised by Gustavsen (2017) in his previous article in NJWLS on Nordic WLDPs as part of the wider QWL movement. 
Discussions on the social effectiveness of WLDPs have been plagued by a lack of an explicit conceptualization of the preconditions for working life change. Without an explicit and a widely shared framework, the accumulation of knowledge in this discussion has been slow. The MLP, with its distinction between three levels of heuristic, analytical concepts, provides one possible way out of this stalemate. As a generic framework that has been widely utilized in (technological) innovation studies, the MLP has potential applicability in the promotion of workplace innovations through WLDPs too. As Rubalcaba et al. (2010, p. 551) argue, the difference between technological and nontechnological innovations is increasingly artificial, since most innovations today are multidimensional.

An explicit conceptual framework like the MLP could be utilized in WLDPs as a means of clarifying and analyzing the system to which the intervention aims to contribute, the landscape of change, and the level of development of potential innovations. Such a framework could also be helpful in designing more realistic program theories, that is, models of how programs are supposed to function and produce the desired processes and outcomes (Dahler-Larsen 2001). Finally, the MLP could yield new insights regarding program evaluations.

The analytical distinction between broadening and scaling-up innovation is another theoretical contribution of Transition Management to the discussion on WLDPs. Broadening and scaling-up are goals with different ambition levels that require a different set of policy tools (Van den Bosch \& Rotmans 2008). The lack of this distinction in mainstream discussion on WLDPs has left this discussion largely vague in its handling of the diffusion problem and of how to move 'upwards' from diffusion. Transition Management has provided insights for both broadening and scaling-up innovation that could benefit the design and implementation of WLDPs.

In this article, the focus has been on programs and the macro level. However, there is no logical reason why utilizing Transition Management as a new means of making sense of efforts to reform working life should be limited to any particular level of analysis. With a little sociological imagination, also other areas of application in working life studies might well be discovered.

\section{References}

Alasoini, T. (2006). In search of generative results: a new generation of programmes to develop work organization, Economic and Industrial Democracy 27(1): 9-37. doi: https://doi. org/10.1177\%2F0143831X06060590.

Alasoini, T. (2009). Strategies to promote workplace innovation: a comparative analysis of nine national and regional approaches, Economic and Industrial Democracy 30(4): 614642. doi: https://doi.org/10.1177\%2F0143831X09336556.

Alasoini, T. (2011). Workplace development as part of broad-based innovation policy: exploiting and exploring three types of knowledge, Nordic Journal of Working Life Studies 1(1): 23-43. doi: https://doi.org/10.19154/njwls.v1i1.2334.

Alasoini, T. (2014). Learning from learning networks: experiences of the Finnish Workplace Development Programme, International Journal of Action Research 10(3): 310-338.

Alasoini, T. (2015). Two decades of programme-based promotion of workplace innovation in Finland: past experiences and future challenges, European Journal of Workplace Innovation 1(1): 37-54. http://journal.uia.no/index.php/EJWI/article/view/160/108. 
Arnkil, R. (2004). The Finnish Workplace Development Programme: a small giant?, Concepts and Transformation 9(3): 249-278. doi: http://dx.doi.org/10.1075/cat.9.3.03arn.

Arnkil, R. (2008). In search of missing links in disseminating good practice: experiences of a work reform programme in Finland, International Journal of Action Research 4(1+2): 39-61.

Arnold, E., Muscio, A., Nählinder, J. \& Reid, A. (2005). Mid-term Evaluation of the VS2010 Programme: A Report to the Research Council of Norway, Brighton: Technopolis.

Battilana, J., Leca, B. \& Boxenbaum, E. (2009). How actors change institutions? Towards a theory of institutional entrepreneurship, Academy of Management Annals 3(1): 65-107. doi: https://doi.org/10.1080/19416520903053598.

Boxall, P. \& Winterton, J. (2018). Which conditions foster high-involvement work processes? A synthesis of the literature agenda for research, Economic and Industrial Democracy 39(1): 27-47. doi: https://doi.org/10.1177/0143831X15599584.

Brulin, G. \& Svensson, L. (2012). Managing Sustainable Development Programmes: A Learning Approach to Change, London: Gower Press.

Budd, J. W., Lamare, J. R. \& Timming, A. R. (2018). Learning about democracy at work: cross-national evidence on the effects of employee participation in workplace decision-making on political participation in civil society, ILR Review 71(4): 956-985. https://doi.org/10.1177/0019793917746619.

Dahler-Larsen, P. (2001). From programme theory to constructivism: on tragic, magic and competing programmes, Evaluation 7(3): 331-349. doi: https://doi.org/10.1177/135638 90122209711.

DiMaggio, P. J. \& Powell, W. W. (1983). The iron cage revisited: institutional isomorphism and collective rationality in organizational fields, American Sociological Review 48(2): 147-160. doi: https://doi.org/10.2307/2095101.

Ekman, M., Gustavsen, B., Asheim, B. T. \& Pålshaugen, Ø. (Eds.) (2011). Learning Regional Innovation: Scandinavian Models, Houndmills: Palgrave Macmillan.

Ennals, R. \& Gustavsen, B. (1999). Work Organization and Europe as a Development Coalition, Amsterdam: John Benjamins.

Gallie, D. (2007). Production regimes, employment regimes, and the quality of work. In D. Gallie (Ed.), Employment Regimes and the Quality of Work (pp. 1-33), Oxford: Oxford University Press.

Geels, F. W. (2004). From sectoral systems of innovation to socio-technical systems: insights about dynamics and change from sociology and institutional theory, Research Policy 33(6-7): 897-920. doi: http://dx.doi.org/10.1016/j.respol.2004.01.015.

Geels, F. W. (2010). Ontologies, socio-technical transitions (to sustainability), and the multilevel perspective, Research Policy 39(4): 495-510. doi: http://dx.doi.org/10.1016/j.respol.2010.01.022.

Geels, F. W. (2011). The multi-level perspective on sustainability transitions: responses to seven criticisms, Environmental Innovation and Societal Transitions 1(1): 24-40. doi: https://doi.org/10.1016/j.eist.2011.02.002.

Geels, F. W., Kern, F., Fuchs, G., Hinderer, N., Kungl, G., Mylan, J., Neukirch, M. \& Wassermann, S. (2016). The enactment of socio-technical transition pathways: a reformulated and a comparative multi-level analysis of the German and UK low-carbon electricity transitions (1990-2014), Research Policy 45(4): 896-913. doi: http://dx.doi.org/10.1016/j. respol.2016.01.015.

Geels, F. W. \& Schot, J. (2007). Typology of sociotechnical transition pathways, Research Policy 36(3): 399-417. doi: http://dx.doi.org/10.1016/j.respol.2007.01.003.

Gustavsen, B. (1992). Dialogue and Development: Theory of Communication, Action Research and the Restructuring of Working Life, Assen: Van Gorcum.

Gustavsen, B. (2003). Action research and the problem of the single case, Concepts and Transformation 8(1): 93-99. doi: http://dx.doi.org/10.1075/cat.8.1.07gus. 
Gustavsen, B. (2007). Work organization and the 'Scandinavian model', Economic and Industrial Democracy 28(4): 650-671. doi: https://doi.org/10.1177/0143831X07082218.

Gustavsen, B. (2011). The Nordic model of work organization, Journal of Knowledge Economy 2(4): 463-480.

Gustavsen, B. (2014). Social impact and the justification of action research knowledge, Action Research 12(4): 339-356. doi: https://doi.org/10.1177/1476750314534455.

Gustavsen, B. (2017). General theory and local action: experiences from the quality of working life movement, Nordic Journal of Working Life Studies 7(S2): 107-120. doi: http:// dx.doi.org/10.18291/njwls.v7iS2.96692.

Gustavsen, B., Finne, H. \& Oscarsson B. (2001). Creating Connectedness: The Role of Social Research in Innovation Policy, Amsterdam: John Benjamins.

Gustavsen, B., Hofmaier, B., Ekman Philips, M. \& Wikman, A. (1996). Concept-driven Development and the Organization of the Process of Change: An Evaluation of the Swedish Working Life Fund, Amsterdam: John Benjamins.

Hansen, K., Amundsen, O., Aasen, T. M. B. \& Gressgård L. J. (2017). Management practices for promoting employee-driven innovation. In P. R. A. Oeij, D. Rus, \& F. D. Pot (Eds.), Workplace Innovation: Theory, Research and Practice (pp. 321-338), Heidelberg: Springer.

Hasle, P. \& Møller, N. (2001). The action plan against repetitive work: an industrial relations strategy for improving the work environment, Human Factors and Ergonomics in Manufacturing 11(2): 131-144. doi: https://doi.org/10.1002/hfm.1004.

Hasle, P., Limborg, H. J., Grøn, S. \& Refslund, B. (2017). Orchestration in work environment policy programs, Nordic Journal of Working Life Studies 7(3): 23-41. doi: http://dx.doi. org/10.18291/njwls.v7i3.97092.

Hildrum, J. M., Finsrud, H. D. \& Klethagen, P. (2009). The next generation of national r\&d programmes in Norway: consequences for action research and regional development, International Journal of Action Research 5(3): 255-288.

Hvid, H. \& Møller, N. (2001). 'The developmental work', Human Factors and Ergonomics in Manufacturing 11(2): 89-100. doi: https://doi.org/10.1002/hfm.1001.

Kauppinen, T. \& Lahtonen, M. (Eds.) (1994). Action Research in Finland, Helsinki: Ministry of Labour.

Kettunen, P. (2012). Reinterpreting the historicity of the Nordic Model, Nordic Journal of Working Life Studies 2(4): 21-43. doi: http://dx.doi.org/10.19154/njwls.v2i4.2303.

Kivimaa, P. \& Kern, F. (2016). Creative destruction or mere niche support? Innovation policy mixes for sustainability transitions, Research Policy 45(1): 205-217. doi: http://dx.doi. org/10.1016/j.respol.2015.09.008.

Kristensen, P. H. (2011). The co-evolution of experimentalist business systems and enabling welfare state. In P. H. Kristensen, \& K. Lilja (Eds.), Nordic Capitalisms and Globalization: New Forms of Economic Organization and Welfare Institutions (pp. 1-46), Oxford: Oxford University Press.

Levin, M. (Ed.) (2002). Researching Enterprise Development: Action Research on the Cooperation between Management and Labour in Norway, Amsterdam: John Benjamins.

Lilja, K. (1992). Finland: no longer the Nordic exception. In A. Ferner, \& R. Hyman (Eds.), Industrial Relations in the New Europe (pp. 198-217), Oxford: Basil Blackwell.

Mustosmäki, A. (2017). How Bright are the Nordic Lights? Job Quality Trends in Nordic Countries in a Comparative Perspective, PhD Thesis, Jyväskylä: University of Jyväskylä.

Naschold, F. (1994). Nationale Programme zur Innovationsentwicklung: Arbeitspolitik in internationalen Vergleich [National innovation development programmes: labour policy in international comparison], Arbeit 3(2): 103-131.

Naschold, F., Cole, R. E., Gustavsen, B. \& Van Beinum, H. (1993). Constructing the New Industrial Society, Assen: Van Gorcum. 
Piirainen, T. \& Koski, P. (2004). Integrating workplace development policy and innovation policy: a challenging task. In W. Fricke, \& P. Totterdill (Eds.), Action Research in Workplace Innovation and Regional Development (pp. 313-331), Amsterdam: John Benjamins.

Qvale, T. U. (2002). A case of slow learning? Recent trends in social partnership in Norway with particular emphasis on workplace democracy, Concepts and Transformation 7(1): 31-55. doi: http://dx.doi.org/10.1075/cat.7.1.04qva.

Ramstad, E. (2009). Developmental evaluation framework for innovation and learning networks: integration of the structure, process and outcomes, Journal of Workplace Learning 21(3): 181-197. doi: https://doi.org/10.1108/13665620910943924.

Ramstad, E. (2014). Can high-involvement innovation practices improve productivity and the quality of working life simultaneously? Management and employee views on comparison, Nordic Journal of Working Life Studies 4(4): 25-45. doi: https://doi.org/10.19154/ njwls.v4i4.4706.

Ramstad, E. \& Alasoini, T. (2006). Interactive research in Finland: workplace research from the 1940's to the present day. In K. Aagaard Nielsen \& L. Svensson (Eds.), Action and Interactive Research: Beyond Practice and Theory (pp. 158-169), Maastricht: Shaker Publishing.

Rubalcaba, L., Gallego, J. \& Den Hertog, P. (2010). The case of market and system failures in services innovation, Service Industries Journal 30(4): 549-566. doi: https://doi. org/10.1080/02642060903067571.

Schot, J. \& Geels, F. W. (2008). Strategic niche management and sustainable innovation journeys: theory, findings, research agenda and policy, Technology Analysis \& Strategic Management 20(5): 537-554. doi: https://doi.org/10.1080/09537320802292651.

Smith, A., Stirling, A. \& Berkhout, F. (2005). The governance of sustainable socio-technical transitions, Research Policy 34(10): 1491-1510. doi: https://doi.org/10.1016/j.respol.2005.07.005.

Smith, A., Voss, J.-P. \& Grin, J. (2010). Innovation studies and sustainability transitions: the allure of the multi-level perspective and its challenges, Research Policy 39(4): 435-448. doi: https://doi.org/10.1016/j.respol.2010.01.023.

Totterdill, P., Exton, O., Exton, R. \& Gold, M. (2016). High-performance work practices in Europe: challenges of diffusion, European Journal of Workplace Innovation 2(1): 63-81. http://journal.uia.no/index.php/EJWI/article/view/355/317.

Van den Bosch, S. \& Rotmans, J (2008). Deepening, Broadening and Scaling Up: A Framework for Steering Transition Experiments, Delft: TNO.

Virkkunen, J. \& Newnham, D. S. (2013). The Change Laboratory: A Tool for Collaborative Development of Work and Education, Rotterdam: Sense Publishers.

Weber, M. K. \& Rohracher, H. (2012). Legitimizing research, technology and innovation policies for transformative change: combining insights from innovation systems and multi-level perspective in a comprehensive 'failures' framework, Research Policy 41(6): 1037-1047. doi: https://doi.org/10.1016/j.respol.2011.10.015. 